\title{
Genotoxic changes in peripheral lymphocytes after therapeutic exposure to crude coal tar and ultraviolet radiation
}

\author{
Andrea Malkova ${ }^{a}$, Renata Kohlerovab ${ }^{b}$, Zdenek Fialaa ${ }^{a}$, Kvetoslava Hamakovac, Iva Selke-Krulichovad ${ }^{d}$, Lenka Borska ${ }^{e}$
}

\begin{abstract}
Aims. Goeckerman therapy is based on combined exposure to UV radiation (UVA, UVB) and crude coal tar (PAHs). Some indicators suggest a genotoxic hazard, however, the level of genotoxic risk of the therapy has not yet been investigated sufficiently. This study aims to assesss the genotoxic risk.

Methods. The studied group consisted of patients with chronic stable plaque psoriasis treated by Goeckerman therapy $(n=29)$. Heparin-treated peripheral blood samples were collected one day before the first treatment and immediately after the last procedure. The lymphocytes were isolated from the blood. The level of genotoxicity was evaluated using an alkaline version of the Comet assay which detects DNA single strand breaks (DNA-SSBs), a neutral version of the Comet assay which detects DNA double strand breaks (DNA-DSBs), and using chromosomal aberrations.

Results. The level of DNA-SSBs increased insignificantly (median; Q1-Q3): 1.4 (0.4; 0.1-1.4) vs. 2.5 (0.6; 0.3-2.7) \%tDNA $(P=0.11)$ and the level of DNA-DSBs increased significantly: $7.8(6.5 ; 3.4-10.5)$ vs. $20.7(19.3 ; 14.2-24.6) \%$ DNA $(P<$ $0.001)$. The total number of aberrated cells $(P<0.001)$ and structurally aberrated cells $(P<0.001)$ increased significantly. Conclusion. The elevated levels of the DNA-DSBs and the chromosomal aberrations in the peripheral lymphocytes indicated a genotoxic hazard. However, the elevated level of the chromosomal abnormalities was below the upper level of the reference range for healthy Czech adults. While, the genotoxic risk appears to be low, Goeckerman treatment represents a further contribution to the lifetime load of genotoxic factors.
\end{abstract}

Key word: crude coal tar, ultraviolet radiation, genotoxicity, comet assay, chromosomal aberrations

Received: January 14, 2016; Accepted with revision: June 1, 2016; Available online: June 9, 2016 http://dx.doi.org/10.5507/bp.2016.032

\begin{abstract}
${ }^{a}$ Department of Hygiene and Preventive Medicine, Faculty of Medicine in Hradec Kralove, Charles University in Prague, Hradec Kralove, Czech Republic

${ }^{b}$ Department of Medical Biochemistry, Faculty of Medicine in Hradec Kralove, Charles University in Prague, Hradec Kralove, Czech Republic 'Clinic of Dermal and Venereal Disease, University Hospital Hradec Kralove, Czech Republic

${ }^{d}$ Department of Medical Biophysic, Faculty of Medicine in Hradec Kralove, Charles University in Prague, Hradec Kralove, Czech Republic e Department of Pathological Physiology, Faculty of Medicine in Hradec Kralove, Charles University in Prague, Hradec Kralove, Czech Republic Coresponding autor: Lenka Borska, e-mail: borka@lfhk.cuni.cz
\end{abstract}

\section{INTRODUCTION}

Psoriasis is a chronic, relapsing and remitting immunemediated inflammatory skin disease with a prevalence of $2-4 \%$ in western countries ${ }^{1,2}$. The etiopathogenesis involves individual genetic predisposition as well as environmental factors.

Topical therapy of psoriasis is now applied in approximately $75 \%$ of cases which are classified as lightly to moderately severe forms ${ }^{3,4}$. In 1925, William H. Goeckerman reported a successful use of topical crude coal tar (CCT) and broad-spectrum ultraviolet radiation (UVA and UVB) in the treatment of psoriasis. This very effective and low cost medical procedure is currently known as the Goeckerman therapy (GT) $\left(\right.$ ref. $\left.^{5}\right)$. However, due to presumed genotoxicity, the use of CCT in dermatology has recently decreased ${ }^{6}$.

The genotoxicity of CCT is related to large content of polycyclic aromatic hydrocarbons (PAHs). Some of them have proven immunosuppressive, mutagenic, genotoxic and carcinogenic effects ${ }^{7}$. They are also photosensitizers and can cause phototoxic effects by way of oxygen-dependent mechanisms ${ }^{8}$. On the other hand, it has been proven that PAHs induced immunosuppression has significant therapeutic effects without symptoms of systemic toxicity $^{6}$.

UVB is a well known factor causing damage to DNA. For a long time, UVA was considered as a weak mutagen because of its lower energy and its limited ability to damage DNA directly. However, the results of recent studies have shown that the UVA can also be a potent inductor of DNA damage and may be associated with skin cancer9. Protracted exposure to UVA leads to lysosomal dysfunction in human fibroblasts ${ }^{10}$, malignant transformation in human cultured keratinocytes ${ }^{11}$ and the formation of skin carcinomas in hairless mice in vivo ${ }^{12}$.

Unlike the shorter-wavelength UVB photons, which are almost completely absorbed by the epidermis, the longerwave length UVA photons can reach deeper dermal layer of skin and its blood vessels. Thus, the peripheral blood cells, including lymphocytes, can be exposed to UVA light even under physiological conditions ${ }^{13}$. The UVA radiation $\left(0.1 \mathrm{~J} / \mathrm{cm}^{2}\right)$ can produce around 80-130 DNA lesions per cell (human lymhocytes) that are detectable by the Comet assay ${ }^{14}$. The combination of UVA and UVB is ranked as carcinogenic to humans according IARC ( ref. $\left.^{7}\right)$. 
Briefly, the CCT (PAHs) and ultraviolet radiation represents therapeutically efficient, nevertheless toxicologically dangerous factors. Moreover, it was proven that UVA in combination with other common environmental pollutants (including PAHs) can significantly increase skin cancer risk ${ }^{15}$. It therefore seems likely, that DNA damage (induced by UVA during GT) can be further increased by co-exposure to PAHs (ref. ${ }^{16}$ ).

DNA is a significant target of environmental stress and the loss of its structural integrity may be a reasonable parameter for assessing susceptibility to mutations ${ }^{17}$. The Comet assay is widely used for assessments of DNA integrity in occupationally and environmentally exposed populations ${ }^{18}$. The assay offers a number of advantages over other methods for the detection of DNA damage: (i) it is rapid, simple, and relatively inexpensive to perform; (ii) it allows for the collection of data at the individual cell level; (iii) it requires a relatively small number of cells $(<10000)$ in each sample; (iv) it shows a high sensitivity for the detection of DNA damage; and (v) almost all types of eukaryotic cells, both in vitro and ex vivo, can be used for analysis ${ }^{19}$. On the other hand, there may be many factors affecting the outcomes of in vitro comet assay, for example, exposure period, sampling period, cells used, S9 components, electrophoresis condition, and cytotoxicity ${ }^{20}$. In the scientific literature, we found no publications that describe the use of Comet assay for genotoxicity evaluation of GT.

It has been proved that chromosomal aberrations in human lymphocytes can predict risk of cancer ${ }^{21}$. The level of chromosomal abnormalities represent well-established biomarker of genotoxicity, probably the only one which has been internationally standardized and validated ${ }^{22,23}$. The declared reference value for the total number of aberrated cells in peripheral lymphocytes of healthy Czech adults ranges from $0.0-2.32 \%$ (ref. $^{22,24}$ ) with no significant correlation to sex or age ${ }^{25}$. Clastogenic activity of PAHs and UV radiation has been clearly demonstrated in human lymphocytes ${ }^{26,27}$ and the genotoxic effect of combined exposure to CCT (PAHs) and UVA/UVB was described in our previous work ${ }^{7}$.

In summary, some indicators suggesting the presence of genotoxic potential (hazard) of therapeutic exposure to CCT (PAHs) and UV radiation. However, the level of genotoxic risk of the therapy has not yet been satisfactorily quantified ${ }^{28,29}$. This study aims to contribute to quantification of the risk.

\section{MATERIALS AND METHODS}

\section{Study group}

The group consisted of patients with chronic stable plaque psoriasis treated by GT (Clinic of Dermal and Venereal Diseases, University Hospital, Hradec Kralove, Czech Republic). Within a period of two years, we collected data on 29 randomly selected adult patients. The study group included 14 women (average age 57 years, age range 30-75 years, 7 smokers) and 15 men (average age 43 years, age range 19-69 years, 9 smokers). The patients who had significant prior exposure to PAHs and/or artificial UVR (especially occupational) were excluded. The study was approved by the Ethics Committee of the University Hospital in Hradec Kralove, Czech Republic. Informed written consent was obtained from each patient.

\section{Goeckerman therapy}

Dermatological ointment ( $5 \%$ of CCT) was administered daily (overnight) on lesions (16-54\% of body surface). Residues of the ointment were removed in the morning (using oil bath) and the patients were wholebody irradiated by ultraviolet radiation (UVA and UVB). The content of selected PAHs in used CCT is described in another article ${ }^{16}$. Duration of the therapy (average duration 11 days; range 3-18 days) was modified according to its effectiveness. The actual status of disease was expressed by using the PASI score (Psoriasis Area and Severity Index) $\left(\right.$ ref. $\left.^{30}\right)$.

\section{Blood samples}

Heparin-treated peripheral blood samples were collected one day before the first treatment and immediately after the last procedure. The samples were placed in the fridge and processed within two hours after collection.

\section{Isolation of peripheral lymphocytes}

The $3 \mathrm{~mL}$ of Histopaque 1077 (Sigma-Aldrich) was overlaid by approximately $2.5-3 \mathrm{~mL}$ of heparinized venous blood. We obtained a white ring which contained lymphocytes by centrifugation $\left(20^{\circ} \mathrm{C}, 400 \mathrm{~g}, 30 \mathrm{~min}\right)$. Lymphocytes were counted and diluted to required concentration of $10^{5}$ cells $/ \mathrm{mL}$.

\section{Comet assay - alkaline version}

The integrity of DNA in peripheral lymphocytes was evaluated using Comet Assay, the common tool for assessment the genotoxicity. A standard version of alkaline comet assay detects DNA single strand breaks (DNASSBs), alkali-labile sites and incomplete excision repair sites $^{31}$. In the presented study we used the standard version with modifications according to Buchynska ${ }^{32}$ and de Freitas ${ }^{33}$. We analysed the percentage of DNA in the tail (designated as tail DNA or tail intensity; \% tDNA) expressed as the ratio between amount of DNA in the head and amount of DNA in the tail ${ }^{34}$.

\section{Comet assay - neutral version}

The DNA double strand breaks (DNA-DSBs) were detected using a neutral version of the Comet assay. We used the modified method described by Olive ${ }^{35}$. The method of preparation of the cells and slides was identical with the alkaline version, up to the phase of lysis of the cells. We omitted the alkaline unwinding and washed the slides three times in the borate buffer $(90 \mathrm{mM}$ Tris, $90 \mathrm{mM}$ boric acid, $2 \mathrm{mM}$ ethylenediaminetetraacetic acid; EDTA) before electrophoresis (borate buffer, $29 \mathrm{~V}, 6 \mathrm{~mA}$ for $40 \mathrm{~min}$ at $4{ }^{\circ} \mathrm{C}$ ). The procedure and evaluation after electrophoresis was analogous to the case of alkaline version. 


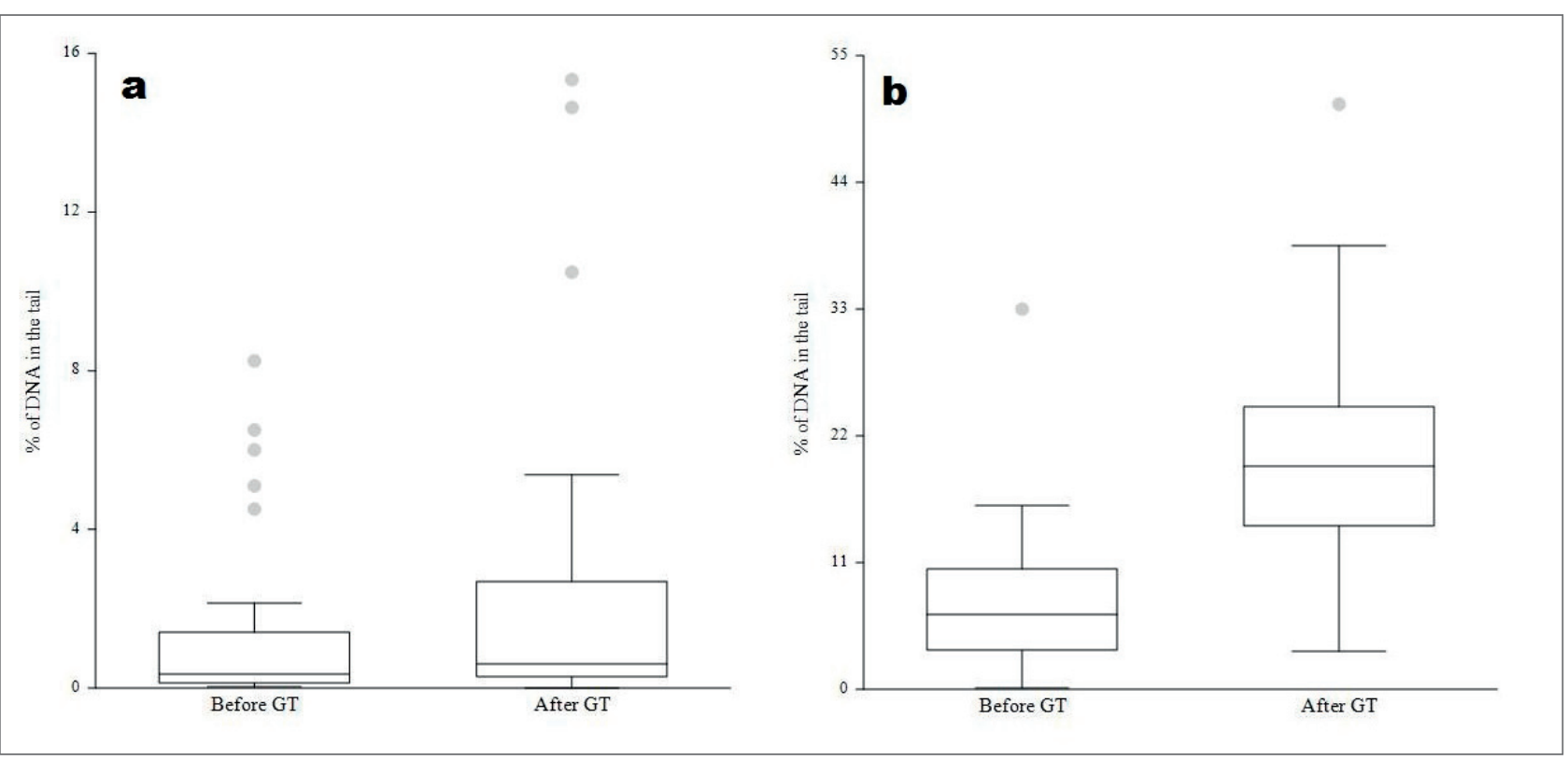

Fig. 1. Comet assay: quantification of DNA breaks (a) DNA-SSBs (alkaline version) and (b) DNA-DSBs (neutral version).

The middle of the box: median

The lower boundary of the box: 1st quartile (Q1)

The upper boundary of the box: 3rd quartile (Q3)

The height of the box: inter-quartile range (IQR)

The lower whisker boundary: the smallest observation that is greater than or equal to Q1 - $1.5 \mathrm{x}$ IQR

The upper whisker boundary: the largest observation that is less than or equal to Q3+1.5 $\mathrm{X}$ IQR

Points outside the whisker boundaries: outliers

\section{Chromosomal aberrations}

The level of chromosomal aberrations in peripheral lymphocytes was evaluated by a standardized method ${ }^{22}$ based on microscopic analysis of lymphocytic chromosomes undergoing mitotic metaphase. In each blood sample, 100 of mitotic sets were evaluated. We measured structurally aberrated cells, numerically aberrated cells and total number of aberrated cells.

\section{Statistical analysis}

Statistical analysis was performed using the NCSS 2007 software ${ }^{36}$. We used Mann-Whitney test for unpaired comparisons and paired $t$-test, Wilcoxon Signed-Rank test, and Sign test for paired comparisons. Pearson correlation and Spearman rank correlation were used to assess relationships between variables (single and double breaks of DNA, number of aberrated cells, PASI score, body surface covered with CCT ointment, overall time of CCT application and overall time of UVR exposure). To keep the family-wise alpha at 0.05 , we used the Bonferroni correction. The resulting significance level for a single test was 0.0021 .

\section{RESULTS}

Daily irradiation of ultraviolet radiation (UVA and UVB) was individual according to disease status (1-15 min). Density of used radiation was $249.75 \mu \mathrm{W} / \mathrm{cm}^{2}$ of UVB and $131.8 \mu \mathrm{W} / \mathrm{cm}^{2}$ of UVA (controlled by SolaScope 2000 spectrometer; Solatell, United Kingdom).
Overall time of exposure to ultraviolet radiation varied from 3 to $122 \mathrm{~min}$ (average time $58 \mathrm{~min}$ ).

Significant decrease in PASI score confirmed the efficacy of GT. Before the therapy, we found (arithmetical mean, SD) $17.5 \pm 5.7$; after the therapy $5.7 \pm 2.4(P<$ 0.001).

The percentage of DNA in the tail obtained in the alkaline version of the Comet assay (\%tDNA) corresponds with the level of the DNA single strand breaks (DNA-SSBs), the alkali-labile sites and the incomplete excision repair sites. The therapy insignificantly increased the level of DNA-SSBs (Fig. 1a). The arithmetic mean of DNA-SSBs (median, first quartile - third quartile; Q1-Q3) reached levels of $1.4(0.4,0.1-1.4) \% \mathrm{tDNA}$ before GT and $2.5(0.6,0.3-2.7) \%$ tDNA after GT $(P=0.11)$.

The percentage of DNA in the tail obtained in the neutral version of the Comet assay (\%tDNA) corresponded with the double strand breaks (DNA-DSBs). DNA-DSBs level was significantly increased due to the therapy (Fig. 1b). The arithmetic mean of DNA-DSBs (median, Q1-Q3) reached levels of $7.8(6.5,3.4-10.5) \%$ tDNA before GT and $20.7(19.3,14.2-24.6) \%$ tDNA after GT $(P<0.001)$.

The therapy significantly increased the total number of aberrated cells $(P<0.001)$ and structurally aberrated cells $(P<0.001)$ (Tab. 1). Before GT, we identified 23 aberrations in the total number of 2900 examined cells $(0.79 \%)$. The aberrations were classified as structural aberrations (19) and numerical aberrations (4). After the therapy, we analyzed 59 aberrations in the total number of 2900 cells $(2.03 \%)$. Aberrations were classified as structural aberrations (49) and numerical aberrations (10). 


\section{DISCUSSION}

This study focused on quantification of the risk of genotoxic potential of combined therapeutic exposure to CCT (PAHs) and ultraviolet radiation. CCT (PAHs) may exert their genotoxic, mutagenic and carcinogenic effects in basically two ways. The first pathway includes formation of specific PAHs-DNA adducts (oxygen-independent reaction with DNA, type I reaction) ( ref. $\left.{ }^{37}\right)$, the second pathway includes induction of oxidative stress (oxygendependent mechanism, type II reaction) (ref. ${ }^{38}$ ). Both of these pathways induce DNA damage (including strand breaks). If left unrepaired, DNA adducts and strand breaks may lead to permanent mutations and chromosomal aberrations ${ }^{39}$ resulting in cell transformation and ultimately to tumour development ${ }^{40}$.

We found no comparable study which evaluated the genotoxic effects of GT using Comet assays (both alkaline and neutral version). In sub-population groups, mildly to moderately exposed to PAHs and UVR, the percentage of DNA in the tail obtained in the Comet assay (alkaline version; DNA-SSBs; \%tDNA) ranged in the order of units. For example Hininger et al. presented an average level (DNA-SSBs; mean \pm SD) of ten healthy non-smokers ( 5 men and 5 women) $4.08 \pm 0.96 \%$ tDNA (ref. ${ }^{41}$ ). Binkova et $\mathrm{al}^{42}$ found in a group of healthy non-smoking women, living in an area polluted by PAHs, the average level of 5.35 and $7.12 \%$ tDNA (DNA-SSBs; medians). Other authors studied a group of policemen who were exposed to combination of PAHs and ultraviolet radiation ${ }^{43}$. In summer they found $2.91 \pm 1.05 \% \mathrm{tDNA}$ (DNA-SSBs; mean \pm SD), in winter $2.42 \pm 1.70 \%$ tDNA. Related control group (non-exposed young healthy males) showed levels $2.62 \pm 1.04 \%$ tDNA (summer) and $2.64 \pm 1.37 \%$ tDNA (winter). Subsequent study (policemen and bus-drivers exposed to PAHs) found levels of $3.86 \pm 1.28 \%$ tDNA (ref. ${ }^{44}$ ).

The GT in our study insignificantly increased the level of DNA-SSBs. In this respect, we note that DNA-SSBs are repaired more than six times faster (within minutes after their formation) than DNA-DSBs ( $r e f{ }^{45}$ ). We assume, that lower levels of DNA damage, detected by the Comet assay (alkaline version), could be related to this fact.

In the case of DNA-DSBs, the literarature concerning PAHs and UVR is very limited. Baumgartner et al. ${ }^{46}$ described elevated levels of DNA-DSBs in lymphocytes (11.08 - 15.23 \%tDNA) after in vitro exposure to benzo(a) pyrene (blood from four healthy non-smoking volunteers). In this study we found significantly increased level of DNA-DSBs $(P<0.001)$. Although DNA-DSBs are less frequent type of DNA lesions upon exposure to ionizing radiation $(\mathrm{SSBs} / \mathrm{DSBs}=25 / 1)$, they are potentially lethal for the cell and more problematic than DNA-SSBs. DNADSBs represent a worse form of DNA damage because the breaks occur on both strands of DNA. The repair of this damage is difficult and slower than the repair of DNA-SSBs and more prone to error due to a lack of undamaged complementary copy ${ }^{14,47}$. The efficacy of DNADSBs repair is crucial for the maintenance of genomic integrity and viability ${ }^{47}$. Failure of that reparation process
Table 1. Chromosomal aberrations in peripheral lymphocytes.

\begin{tabular}{|c|c|c|c|c|c|c|}
\hline \multirow{2}{*}{ 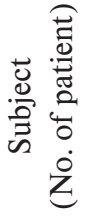 } & \multicolumn{3}{|c|}{$\begin{array}{c}\text { Chromomal aberration } \\
\text { before GT }\end{array}$} & \multicolumn{3}{|c|}{$\begin{array}{c}\text { Chromomal aberration } \\
\text { after GT }\end{array}$} \\
\hline & $\mathrm{ABC}$ & SAC & NAC & $\mathrm{ABC}$ & SAC & NAC \\
\hline 1 & 1 & 1 & 0 & 5 & 5 & 0 \\
\hline 2 & 1 & 1 & 0 & 2 & 2 & 0 \\
\hline 3 & 1 & 1 & 0 & 2 & 2 & 0 \\
\hline 4 & 0 & 0 & 0 & 1 & 1 & 0 \\
\hline 5 & 3 & 3 & 0 & 4 & 4 & 0 \\
\hline 6 & 0 & 0 & 0 & 1 & 0 & 1 \\
\hline 7 & 1 & 0 & 1 & 3 & 3 & 0 \\
\hline 8 & 0 & 0 & 0 & 1 & 1 & 0 \\
\hline 9 & 1 & 1 & 0 & 2 & 2 & 0 \\
\hline 10 & 0 & 0 & 0 & 1 & 1 & 0 \\
\hline 11 & 2 & 1 & 1 & 3 & 2 & 1 \\
\hline 12 & 1 & 1 & 0 & 2 & 1 & 1 \\
\hline 13 & 0 & 0 & 0 & 3 & 2 & 1 \\
\hline 14 & 2 & 2 & 0 & 3 & 1 & 2 \\
\hline 15 & 0 & 0 & 0 & 1 & 1 & 0 \\
\hline 16 & 0 & 0 & 0 & 2 & 1 & 1 \\
\hline 17 & 0 & 0 & 0 & 2 & 2 & 0 \\
\hline 18 & 2 & 2 & 0 & 3 & 2 & 1 \\
\hline 19 & 1 & 0 & 1 & 3 & 2 & 1 \\
\hline 20 & 0 & 0 & 0 & 1 & 0 & 1 \\
\hline 21 & 1 & 1 & 0 & 5 & 5 & 0 \\
\hline 22 & 1 & 0 & 1 & 0 & 0 & 0 \\
\hline 23 & 2 & 2 & 0 & 1 & 1 & 0 \\
\hline 24 & 0 & 0 & 0 & 1 & 1 & 0 \\
\hline 25 & 1 & 1 & 0 & 3 & 3 & 0 \\
\hline 26 & 0 & 0 & 0 & 1 & 1 & 0 \\
\hline 27 & 1 & 1 & 0 & 1 & 1 & 0 \\
\hline 28 & 1 & 1 & 0 & 1 & 1 & 0 \\
\hline 29 & 0 & 0 & 0 & 1 & 1 & 0 \\
\hline
\end{tabular}

$\mathrm{ABC}$ : total number of aberrated cells

SAC: structurally aberrated cells

NAC: numerically aberrated cells

can lead to cell death or its malignant transformation ${ }^{48}$ through the induction of chromosomal aberrations ${ }^{39}$.

The literature reports that UVA induces a dose-dependent increase in the level of DNA damage, detected by the alkaline version of the Comet assay, and in oxidative stress, characterized by increased level of 8-oxo-7,8-dihydroguanine ${ }^{14,49}$. It is not known whether UVA can directly cause DNA-DSBs, but DNA-DSBs occur during repair of oxidative damage ${ }^{49}$. In this work, we studied the effects of combined exposure to ultraviolet radiation and PAHs. Under these exposure conditions we found no significant relationship between exposure to ultraviolet radiation and the level of genotoxicity (expressed as DNA-SSBs or DNA-DSBs).

As stated above, DNA-DSBs occur less frequently, are roughly six times more slowly repaired (compared to DNA SSBs) and can be detected with a certain time delay 
from exposure. With regard to the nature of evaluated subchronic exposure (GT), we assume that for purposes of biological monitoring, monitoring the levels DNA-DSBs is (in this case) more appropriate.

Apart from our earlier publications ${ }^{6,16}$ we found no publication on evaluation of genotoxic effects of GT using chromosomal aberrations in human lymphocytes. Among the other recent works, we can choose e.g. a study aimed at the genotoxic risk of traffic policemen (combined exposure to PAHs and ultraviolet radiation). The mean level of chromosomal aberrations in lymphocytes (observed in different cities and different seasons) ranged from 0.22 to $0.27 \% \mathrm{ABC}\left(\right.$ ref. $\left.^{50}\right)$.

It is evident that the therapy significantly increases absolute level of aberrated cells $(P<0.001)$ and thus increases the related genotoxic risk. However, it must be emphasized that the level of abnormalities found after the therapy $(2.03 \%)$ was still below the upper level of the reference range for healthy $\mathrm{Czech}$ adults.

\section{CONCLUSION}

While the values of DNA-SSBs ranged within the level of normal non-exposed populations, elevated levels of the DNA-DSBs indicated the genotoxic risk. The risk was also suggested by the elevated levels of chromosomal aberrations; however, the level of chromosomal abnormalities was below the upper level of the reference range for healthy Czech adults. In summary, the level of genotoxic risk appears to be low. On the other hand, it is evident that assessed effective therapy represents a significant contribution to the lifetime load of genotoxic factors.

\section{ABBREVIATIONS}

$\%$ tDNA, Percentage of DNA in the tail; ABC, Total number of aberrated cells; CCT, Crude coal tar; DNA-DSBs, Double strand breaks; EDTA, Ethylenediaminetetraacetic acid; PAHs, Polycyclic aromatic hydrocarbons; PASI, Psoriasis area and severity index; DNA-SSBs, Single strand breaks.

Acknowledgment: Supported by Charles University in Prague, Faculty of Medicine in Hradec Kralove, Czech Republic, project PRVOUK P37/09 and PRVOUK P37/01. The authors thank Dana Knajflová for proofreading.

Author contributions: LB, ZF: study design; LB, RK, $\mathrm{KH}$ : performed the experiments; ISK: data analysis; AM, LB,ZF: manuscript writing.

Conflict of interest statement: The authors state that there are no conflicts of interest regarding the publication of this article.

\section{REFERENCES}

1. Gupta R, Debbaneh M, Butler D, Huynh M, Levin E, Leon A, Koo J, Liao W. The Goeckerman regimen for the treatment of moderate to severe psoriasis. J Vis Exp 2013(77):e50509.

2. Borska L, Andrys C, Krejsek J, Palicka V, Vorisek V, Hamakova K, Kremlacek J, Borsky P, Fiala Z. Influence of dermal exposure to ultraviolet radiation and coal tar (polycyclic aromatic hydrocarbons) on the skin aging process. J Dermatol Sci 2016;81(3):192-202.

3. Zampetti A, Barone A, Antuzzi D, Amerio P, Tulli A, Feliciani C, Amerio P. Topical preparations for the treatment of psoriasis: results of a retrospective study over 15 years. J Dermatolog Treat 2008;19(3):13440.

4. Moscaliuc ML, Heller MM, Lee ES, Koo J. Goeckerman therapy: a very effective, yet often forgotten treatment for severe generalized psoriasis. J Dermatolog Treat 2013;24(1):34-7.

5. Steele T, Pawaskar M, Balkrishnan R, Fleischer A, Feldman SR. Does cost-effectiveness play a role in clinical trials? Dermatol Ther 2007;20(2):110-9.

6. Borska L, Fiala Z, Andrys C, Krejsek J, Hamakova K. Goeckerman regimen: genotoxic, pro-apoptotic, anti-inflammatory and anti-angiogenic effect. Dermatology Research: Focus on Acne, Melanoma, and Psoriasis 2010;11788:141-65.

7. IARC. IARC Monographs on the evaluation of Carcinogenic Risks to Human. Agents Classified by the IARC Monographs. International Agency for Research on Cancer. Lyon: Cedex 08 2014:1-109.

8. Cosmetic Ingredient Review Expert Panel. Final safety assessment of Coal Tar as used in cosmetics. Int J Toxicol 2008;27 Suppl 2:1-24.

9. Sage E, Girard PM, Francesconi S. Unravelling UVA-induced mutagenesis. Photochem Photobiol Sci 2012;11(1):74-80.

10. Lamore SD, Wondrak GT. UVA causes dual inactivation of cathepsin $B$ and $L$ underlying lysosomal dysfunction in human dermal fibroblasts. J Photochem Photobiol B 2013;123:1-12.

11. He YY, Pi J, Huang JL, Diwan BA, Waalkes MP, Chignell CF. Chronic UVA irradiation of human $\mathrm{HaCaT}$ keratinocytes induces malignant transformation associated with acquired apoptotic resistance. Oncogene 2006;25(26):3680-8.

12. de Laat A, van der Leun JC, de Gruijl FR. Carcinogenesis induced by UVA (365-nm) radiation: the dose-time dependence of tumor formation in hairless mice. Carcinogenesis 1997;18(5):1013-20.

13. Svobodova AR, Galandakova A, Sianska J, Dolezal D, Lichnovska R, Ulrichova J, Vostalova J. DNA damage after acute exposure of mice skin to physiological doses of UVB and UVA light. Arch Dermatol Res 2012;304(5):407-12.

14. Osipov AN, Smetanina NM, Pustovalova MV, Arkhangelskaya E, Klokov D. The formation of DNA single-strand breaks and alkalilabile sites in human blood lymphocytes exposed to 365-nm UVA radiation. Free Radic Biol Med 2014;73:34-40.

15. Burke KE, Wei H. Synergistic damage by UVA radiation and pollutants. Toxicol Ind Health 2009;25(4-5):219-24.

16. Borska L, Andrys C, Krejsek J, Palicka V, Chmelarova M, Hamakova K, Kremlacek J, Fiala Z. Oxidative Damage to Nucleic Acids and Benzo(a) pyrene-7,8-diol-9,10-epoxide-DNA Adducts and Chromosomal Aberration in Children with Psoriasis Repeatedly Exposed to Crude Coal Tar Ointment and UV Radiation. Oxidative Medicine and Cellular Longevity 2014;2014:10.

17. Avery SV. Molecular targets of oxidative stress. Biochem J 2011;434(2):201-10.

18. Jayakumar R, Sasikala K. Evaluation of DNA damage in jewellery workers occupationally exposed to nitric oxide. Environ Toxicol Pharmacol 2008;26(2):259-61.

19. Olive PL, Banath JP. The comet assay: a method to measure DNA damage in individual cells. Nat Protoc 2006;1(1):23-9.

20. Sasaki YF, Nakamura T, Kawaguchi S. What is better experimental design for in vitro comet assay to detect chemical genotoxicity? 2008:449-504.

21. Chandirasekar R, Kumar BL, Sasikala K, Jayakumar R, Suresh K, Venkatesan R, Jacob R, Krishnapriya EK, Kavitha H, Ganesh GK. Assessment of genotoxic and molecular mechanisms of cancer risk in smoking and smokeless tobacco users. Mutat Res Genet Toxicol Environ Mutagen 2014;767:21-7.

22. Cerna M, Spevackova V, Batariova A, Smid J, Cejchanova M Ocadlikova D, Bavorova H, Benes B, Kubinova R. Human biomonitor- 
ing system in the Czech Republic. International Journal of Hygiene and Environmental Health 2007;210(3-4):495-9.

23. Moretti M, Bonfiglioli R, Feretti D, Pavanello S, Mussi F, Grollino MG, Villarini M, Barbieri A, Ceretti E, Carrieri M, Buschini A, Appolloni M, Dominici L, Sabatini L, Gelatti U, Bartolucci GB, Poli P, Stronati L, Mastrangelo G, Monarca S. A study protocol for the evaluation of occupational mutagenic/carcinogenic risks in subjects exposed to antineoplastic drugs: a multicentric project. BMC Public Health 2011;11:195

24. AHEM. Standardized operating approaches for biological monitoring of genotoxic of environmental factors. Acta Hygienica, Epidemiologica et Microbiologica 2003;3:6-17.

25. Merlo DF, Ceppi M, Stagi E, Bocchini V, Sram RJ, Rössner P. Baseline chromosome aberrations in children. Toxicology Letters 2007;172(12):60-7.

26. Urushibara A, Kodama S, Yokoya A. Induction of genetic instability by transfer of a UV-A-irradiated chromosome. Mutat Res Genet Toxicol Environ Mutagen 2014;766:29-34.

27. Wang Y, Yang H, Li L, Wang H, Xia X, Zhang C. Biomarkers of chromosomal damage in peripheral blood lymphocytes induced by polycyclic aromatic hydrocarbons: a meta-analysis. Int Arch Occup Environ Health 2012;85(1):13-25.

28. Roelofzen $\mathrm{JH}$, Aben $\mathrm{KK}$, van der Valk PG, van Houtum JL, van de Kerkhof PC, Kiemeney LA. Coal tar in dermatology. J Dermatolog Treat 2007;18(6):329-34.

29. Ranna D, Andrys C, Krejsek J, Hamakova K, Kremlacek J, Fiala Z, Borsky P, Borska L. Elevated levels of circulating biomarkers of cell death (nucleosomes) in the patients with plaque psoriasis treated with the Goeckerman regimen. Bratisl Lek Listy 2014;115(4):229-32.

30. de Rie MA, Goedkoop AY, Bos JD. Overview of psoriasis. Dermatol Ther 2004;17(5):341-9.

31. Hoffmann H, Speit G. Assessment of DNA damage in peripheral blood of heavy smokers with the comet assay and the micronucleus test. Mutation Research/Genetic Toxicology and Environmental Mutagenesis 2005;581(1-2):105-14.

32. Buchynska L, Brieieva O, Glushchenko N, Vorobyova L, Bilyk O. DNA repair deficiency in peripheral blood lymphocytes of endometrial cancer patients with a family history of cancer. BMC Cancer 2014;14:765.

33. de Freitas TA, Palazzo RP, de Andrade FM, Reichert CL, Pechansky F, Kessler F, de Farias CB, de Andrade GG, Leistner-Segal S, Maluf SW. Genomic instability in human lymphocytes from male users of crack cocaine. Int J Environ Res Public Health 2014;11(10):10003-15.

34. Collins A, Koppen G, Valdiglesias V, Dusinska M, Kruszewski M, Møller P, Rojas E, Dhawan A, Benzie I, Coskun E, Moretti M, Speit G, Bonassi $\mathrm{S}$. The comet assay as a tool for human biomonitoring studies: The ComNet Project. Mutation Research/Reviews in Mutation Research 2014;759(0):27-39.

35. Olive PL, Wlodek D, Banath JP. DNA double-strand breaks measured in individual cells subjected to gel electrophoresis. Cancer Res 1991;51(17):4671-6.

36. Hintze J. NCSS, PASS, and GESS. NCSS. Kaysville, Utah 2007.

37. Marczynski B, Raulf-Heimsoth M, Spickenheuer A, Pesch B, Kendzia $B$, Mensing T, Engelhardt B, Lee EH, Schindler BK, Heinze E, Welge $P$, Bramer R, Angerer J, Breuer D, Kafferlein HU, Bruning T. DNA adducts and strand breaks in workers exposed to vapours and aerosols of bitumen: associations between exposure and effect. Arch Toxicol 2011;85 Suppl 1:S53-64.

38. Moustafa GA, Xanthopoulou E, Riza E, Linos A. Skin disease after occupational dermal exposure to coal tar: a review of the scientific literature. Int J Dermatol 2015;54(8):868-79.

39. Obe $G$, Johannes $C$, Ritter $S$. The number and not the molecular structure of DNA double-strand breaks is more important for the formation of chromosomal aberrations: a hypothesis. Mutat Res 2010;701(1):3-11

40. Pauk N, Klimesova S, Kara J, Topinka J, Labaj J. The relevance of monitoring of antibodies against the polycyclic aromatic hydrocarbon (PAH) and PAH-DNA adducts in serum in relation to lung cancer and chronic obstructive pulmonary disease (COPD). Neoplasma 2013;60(2):182-7.

41. Hininger I, Chollat-Namy A, Sauvaigo S, Osman M, Faure H, Cadet J, Favier A, Roussel A-M. Assessment of DNA damage by comet assay on frozen total blood: method and evaluation in smokers and nonsmokers. Mutation Research/Genetic Toxicology and Environmental Mutagenesis 2004;558(1-2):75-80.

42. Binková B, Lewtas J, Mísková I, Rössner P, Cerná M, Mrácková G, Peterková K, Mumford J, Meyer S, Srám R. Biomarker studies in northern Bohemia. Environmental Health Perspectives 1996;104(Suppl 3):591-7.

43. Cebulska-Wasilewska A, Wiechec A, Panek A, Binkova B, Sram RJ, Farmer PB. Influence of environmental exposure to PAHs on the susceptibility of lymphocytes to DNA-damage induction and on their repair capacity. Mutat Res 2005;588(2):73-81.

44. Cebulska-Wasilewska A, Pawlyk I, Panek A, Wiechec A, Kalina I, Popov T, Georgieva T, Farmer PB. Exposure to environmental polycyclic aromatic hydrocarbons: influences on cellular susceptibility to DNA damage (sampling Kosice and Sofia). Mutat Res 2007;620(1-2):14554.

45. Rapp A, Greulich KO. After double-strand break induction by UV$A$, homologous recombination and nonhomologous end joining cooperate at the same DSB if both systems are available. J Cell Sci 2004;117(Pt 21):4935-45.

46. Baumgartner A, Kurzawa-Zegota M, Laubenthal J, Cemeli E, Anderson D. Comet-assay parameters as rapid biomarkers of exposure to dietary/environmental compounds-An in vitro feasibility study on spermatozoa and lymphocytes. Mutation Research/Genetic Toxicology and Environmental Mutagenesis 2012;743(1-2):25-35.

47. Hakem R. DNA-damage repair; the good, the bad, and the ugly. EMBO J 2008:27(4):589-605.

48. Yang S, Chintapalli J, Sodagum L, Baskin S, Malhotra A, Reiss K, Meggs LG. Activated IGF-1R inhibits hyperglycemia-induced DNA damage and promotes DNA repair by homologous recombination. Am J Physiol Renal Physiol 2005;289(5):F1144-52.

49. Greinert R, Volkmer B, Henning S, Breitbart EW, Greulich KO, Cardoso MC, Rapp A. UVA-induced DNA double-strand breaks result from the repair of clustered oxidative DNA damages. Nucleic Acids Res 2012;40(20):10263-73.

50. Rossner P, Jr., Rossnerova A, Spatova M, Beskid O, Uhlirova K, Libalova H, Solansky I, Topinka J, Sram RJ. Analysis of biomarkers in a Czech population exposed to heavy air pollution. Part II: chromosomal aberrations and oxidative stress. Mutagenesis 2013;28(1):97106. 